ability to increase the frequency of the gene responsible for their disorder in the general population.

Many individuals have, in our opinion, become unduly alarmed about the possible effects of this increased fitness upon the total gene pool, and have stated their concern that "bad" genes will rapidly increase in frequency until they replace "good" ones. We believe, that these fears are unwarranted for three reasons:

First, human mutation rates are extremely low (in the range of $10^{-5} /$ gamete/generation). Were "fitness" of affected individuals raised to the level of the general population, several generations would be required before the frequency of the gene in question would be doubled. Furthermore, improvements in "fitness" are rarely complete; most situations result merely in the establishment of a new equilibrium at a gene frequency slightly higher than that which prevailed initially.

Second, we have, by instituting programs of detection and therapy, removed, to a varying degree, the disability associated with these disorders. To the extent that these programs are effective we have made it possible for affected individuals to lead more normal and productive lives; they may make great contributions to society. Thus they have, by definition, become "fit."

Finally, the individual consequences of hereditary disease can be so drastic that many married couples who knowingly carry deleterious genes for disorders such as retinoblastoma or phenylketo- nuria are not likely to wish to risk propagating these traits in their children. Many may voluntarily choose to utilize the highly effective methods now available for control of reproduction, and seek alternate pathways for the realization of family life. Some may wish to adopt families; in appropriate cases voluntary choice of germ plasm and artificial insemination may permit couples to bear children while controlling the genetic contribution of the husband.

Thus, it is our opinion that the fears raised regarding the effect of early detection and care of genetic disorders upon the general gene pool are largely unwarranted. Attention should more appropriately be directed toward the individuals and families affected by these disorders; this is where the major impact is felt, and where total care is most needed.

Such a program of total care, which should include voluntary negative eugenics, calls for expanded and new community health services. Clinical and laboratory procedures for the diagnosis of affected individuals and carrier states must become generally available. Genetic counselling and, where indicated, artificial insemination, must be made accessible and legally feasible. Regrettably, at present, very few American communities have even one of these services available.-WARREN WINKEL stein, JR., M.D., M.P.H., Davm L. SACKETT, M.D., M.S.EPID., Departments of Preventive Medicine and Medicine, State University of New York at Buffalo School of Medicine.

\title{
Some Fundamentals of Emotional Growth in Children
}

\begin{abstract}
$T_{1}$
HE pediatrician should have a reasonably clear awareness of the various emotional phases through which children proceed as they develop normally. When he reassures a mother that her child will "outgrow" a particular problem, he should do so only because he knows from this yard. stick of developmental phenomena that those symptoms which the child is demonstrating are normal at his present age, but at another age might be signals of an emotional disorder requiring psychiatric intervention. He should never tell a mother that her child will outgrow a prob. lem because of his own uncertainty and frustrations at not knowing what else to say.
\end{abstract}

The physician should know how the individual child's personality is formed; it is a gradual process of passing through a series of phases. The pediatrician should also be thoroughly familiar with the concept that that part of the mind and personality which is under conscious woluntary control can be appealed to reasonably and logically, but that the largest part is not, and that this part of the mind has to be approached differently.

\section{Development of Personality}

Let us outline briefly the developmental phases of our personality, in order to provide a rough yardstick of normality from year to year. These phases can be condensed schematically as follows: 


\begin{tabular}{|c|c|c|}
\hline Phase & Age & Task to be Accomplished \\
\hline Infancy & $0-1$ year & $\begin{array}{l}\text { Basic feelings toward the world } \\
\text { are achieved-trust, security, } \\
\text { optimism about the future }\end{array}$ \\
\hline Preschool & $1-4$ years & $\begin{array}{l}\text { Individuality and independ- } \\
\text { ence achieved }\end{array}$ \\
\hline Kindergarten & \pm-6 years & $\begin{array}{l}\text { Differences between males and } \\
\text { females become important }\end{array}$ \\
\hline Grade school years & $7-12$ years & $\begin{array}{l}\text { Assumes masculine or feminine } \\
\text { role in life, mastery of prob- } \\
\text { lems outside the family unit, } \\
\text { mental energy devoted to } \\
\text { learning in school and de- } \\
\text { veloping motor skills }\end{array}$ \\
\hline Adolescence & $13-19$ years & $\begin{array}{l}\text { Emancipation from parents } \\
\text { and heterosexual adjustment }\end{array}$ \\
\hline Adulthood & 20 onward & Continued emotional growth \\
\hline
\end{tabular}

Normal Emotional Characteristics

Helpless, dependent, responsive to mother's feelings and attitude

Messy, stubborn, prone to temper tantrums when frustrated, selish, bossy

Sexual curiosity, jealousy and antagonism toward parent of the opposite sex

Prefers children of own sex, emphasis on fairness and justice, secrets kept from adults

Stormy, unpredictable, moody, crushes and falling in love, resentful of adults

Ability to work, love, and contribute to community

\section{Structure of Personality}

Next we will review briefly the "parts" of the mind. The mind is not a "thing" but a system of functions which develop in a complementary way.

The first element in the system is inborn. Each individual is born with a large reservoir of inherited instincts, pleasure-seeking and self-preservative, which control his life at the beginning. This is the "animal" part of man, called the id by psychiatrists. The total absorption of the body in satisfying its needs is evident in the hungry infant who is screaming, choking, crying, red all over, simultaneously releasing his sphincters.

After the first few months, we begin to see another part of the mind develop-the rational, civilized part which provides for conscious awareness of others and the gradually increasing ability to conform, control and delay the expression of bodily needs. This "self" or ego, as it is called in psychiatric terminology, differs from person to person in strength, flexibility, and capacity to adapt, accounting for many individual variations.

This aspect of the mind, the ego, as it assumes control over the more primitive part, is greatly assisted by a helper after about five years of lifethe conscience, or roughly, the superego. This part tays down rules of morality and standards of right or wrong upon which we decide to act or not to act. Its weapon is guilt, and it is powerful indeed.

In mentally healthy individuals, these three functional system mesh hamponionsw. The needs and instincts are usually satisfied when appropriate, sometimes diverted, and sometimes sup. pressed by the ego. Meanwhile the conscience assists as a giver of advice as to what is reasonable expression and what is not. When this equilibrium is tipped, when instincts gain sway in an individual's life, or even when the opposite extreme occurs, then the conscience becomes so harsh and dictatorial that it will not allow any pleasurable or self-assertive expression. We then see conflict and symptoms of mental illness.

\section{Conscious-Unconscious}

A knowledge of the concept of the unconscious mind is a sine qua non for dealing with emotional problems. Understanding the concept explains why patients cannot "snap out of it" when they are so advised, or cannot cheer up when we try to reassure and support them. These patients are at the mercy of deeper layers of the mind which they cannot control rationally or logically.

We experience the phenomenon of the unconscious in ourselves when we forget names, usually certain names, or certain pieces of information; for example, we may forget our wedding anniversary after a marital quarrel. We see the power. ful forces of the unconscious mind operating in mental illness, where, for example, there is no logical explanation from the individual's previous experience for his incapacitating fear of heights or spaces. Dreams are an example of the unconscious breaking through in everyone at night. Hypnosis is a phenomenon through which impulses can be expressed without conscious awareness.

The largest part of our mind is the unconscious. It goes by no rules, nor will at be controlled by the conscious. The conscious or smallest part of the mind is that area in which logical houghts and behavior prevails. There is an "in-between" gray area which we call the preconscious mind its which memory traces remain and are available to recall, if we focus attention on them and try to bring back information which has been put into the back of our mind.

It is important diagnostically to estimate how much of a patient's behavior is under conscious control as compared with how much is being driven by forces over which he has no control be- 
cause he is unaware of them. The way in which we attempt to help or influence children and their parents differs according to our estimate of the proportion of conscious or unconscious control the child has over his behavior.

Furthermore, the clinical importance of our understanding of the unconscious mind cannot be overstressed; hidden in it are the reasons why families often react in puzzling ways to a doctor's advice. The average family develops strong emotional ties to the pediatrician, yet sees him in realistic ways. The family accepts his advice and suggestions and carries them out within the frame. work of a mature doctor-patient relationship.

Other families, however, are overly dependent and clinging in an infantile way; or they act like older children who need constant guidance and direction. If childish attitudes of another kind prevail, parents may refuse to follow the doctor's reasonable advice and either openly or covertly rebel against whatever he says. These individuals neither understand nor are aware of these tend. encies in themselves, for their roots are in the unconscious mind. They extend back in their own lives to their attitudes and feelings toward their own parents, and represent a persistent repetition of the same habits and patterns of behavior toward people, in this case the pediatrician, regardless of different situations.

In the child who does not listen to the doctor or who is overly dependent, the problem is perhaps less complicated. His attitude toward his doctor can often be seen as a direct reaction which is displaced from habitual attitudes and feelings toward his parents at home-fear, resentment, opposition, whining dependence, etc. In any case, such "transference" must be understood and handled properly by the physician. He must sometimes even do his best despite such obstacles, instead of reacting to them as if they were personal insults. At times, the physician may even uncover the origins of the child's or his family's abnormal behavior. He can then discuss with the individual his past life and relate it to his present attitude. This may help a patient to see the inappropriateness of his stereotyped, repetitive behavior.-Extracted from a forthcoming book by StuarT M. FINGH, M.D., and John F. MCDERMotr, JR., M.D. Dr. Finch is Professor of Psychiatry and Dr. McDermott is As. sociate Professor of Psychiatry at the University of Michigan Medical School, Ann Arbor, Michigan.

\section{Educating the Doctor About Drug Costs}

\begin{abstract}
A $S$ has often been pointed out, in most producer-consumer situations it is the consumer who alone decides what he will buy. With most drug decisions, however, the physician is the most important person, though he neither uses nor pays for the drug he orders. Many factors influence the physician's decisions as the consumer's "purchasing agent," yet the patient rarely is appraised of these factors.

This somewhat unique situation can be consid. ered from two points of view: (a) the consumer is denied decision making or (b) the consumer benefits by having one more capable than he in such decision making. Indeed, were the implications not so serious, it woude be iudicrous for the consumer to make most decisions. Some have advocated that he interrogate the physician to assure that the physician is doing right by his drug needs. Yet, this is the same physician whom he chooses to trust with his very life.

Since the physician either writes prescriptions for drugs or suggests O.T.C. (over the counter) drugs or household remedies, his attitudes as re-
\end{abstract}

llected from his education and his experience play a most significant role in determining part of drug costs.

In the preclinical years, and particularly in pharmacology, the student is taught the error of de. pending on hunches or "clinical judgment," and the need for controlled experiments before making judgment either at this time or later in his prescribing life. This knowledge added to a sound foundation in general pharmacology may permit him to meet the kind of "education" which he faces in the professional clinical journals, those less professional, and those which are purchased, given free, or even thrown at him. He should soon learn that advertising can be and is a form of "educationa" but must always be evaluated in terms of its source. For even the most professional journals of the learned societies are like the "two faces of Janus," as related to the content between the two covers. Certainly, the same editorial examination and scrutiny are not airned at the scientific as at the advertising halves. He should understand most journals must "live" on the dollars derived from 